\title{
Selective oestrogen receptor antagonists inhibit oesophageal cancer cell proliferation in vitro
}

Waleed Al-Khyatt ${ }^{1,2^{*}}$, Cristina Tufarelli ${ }^{2}$, Raheela Khan ${ }^{2^{*}}$ and Syed Yousef Iftikhar ${ }^{1,2}$

\begin{abstract}
Background: Oestrogen receptors (ER) have a well-established role to the initiation, progression and regulation of responses to treatment of breast, prostate, and lung cancers. Previous data indicates altered ER expression in oesophageal cancers (OC). However the role of ER subtypes and ER specific inhibitors in the regulation of OC progression remains unclear. This study sought to assess levels of ERa and ERß in OC. The effects of highly selective ER antagonists on cell proliferation and apoptosis in two OC adenocarcinoma cell lines was also studied.
\end{abstract}

Methods: ERa and ER $\beta$ expression profiling in paired normal oesophageal mucosa and tumour tissues $(n=34$; adenocarcinoma $n=28$; squamous cell carcinoma $n=6$ ) was performed using quantitative reverse transcription polymerase chain reaction (qRT-PCR). Correlation between levels of ER with the clinico-pathological features for OC was determined. The effect of selective ER antagonists on proliferation of OE33 and OE19 OC cell lines was studied.

Results: ERa and ER $\beta$ mRNA expression was significantly higher $(p<0.05)$ in tumour tissues relative to their paired normal mucosa and correlated inversely with survival outcome $(p<0.05)$. Upregulation of ERa mRNA correlated with higher pathological T-stage $(p<0.05)$ and lymph node metastasis $(p<0.05)$ while ER $\beta$ mRNA upregulation correlated with positive vascular invasion $(p<0.05)$. A significant concentration-dependent inhibition of proliferation in OE33 and OE19 cell lines was induced by a highly-selective ERa antagonist (MPP) and an ERß specific antagonist (PHTPP) $(p<0$. 05). Moreover, anti-oestrogens induced cell death through stimulation of apoptotic caspase activity.

Conclusion: These findings indicate that the ER system is involved in OC progression and thus may provide a novel target for the treatment of OC.

Keywords: Oestrogen, Receptors, Alpha, Beta, Oesophageal, Cancer, Adenocarcinoma, Squamous, Male, Female, Sex, Hormones, Treatment

\section{Background}

Oesophageal cancer $(\mathrm{OC})$ is the eighth most common cancer and the sixth most common cause of cancer mortality worldwide [1]. Despite developments in treatment modalities, estimated overall five-year survival rate for patients with $\mathrm{OC}$ is still poor [2,3]. It is evident that surgery alone is not a curative option for all stages of

\footnotetext{
* Correspondence: waleed.al-khyatt@nhs.net; raheela.khan@nottingham.ac.uk 'Department of Upper GI Surgery, Royal Derby Hospital, Derby Teaching Hospitals NHS Foundation Trust, Uttoxeter Road, Derby DE22 3NE, UK ${ }^{2}$ Division of Medical Sciences and Graduate Entry Medicine, Royal Derby Hospital, Uttoxeter Road, Derby DE22 3DT, UK
}

$\mathrm{OC}$ and additional adjunctive treatment modalities are needed $[4,5]$.

One of the characteristic features of OC, especially oesophageal adenocarcinoma (AC) is a persistence gender bias over several decades, in all races and across the world [6]. It occurs more frequently in males than in females, with a male to female ratio of $5-10: 1$, a fact that remains unexplained [7-9]. Besides, most published evidence fails so far to address any significant difference in exposure to known risk factors for the disease [10]. Instead, it is suggested that the hormonal milieu may play a possible role in this gender bias [11-15]. In support of this, the Women's Health Initiative (WHI) study 
identified that the risk of developing $\mathrm{OC}$ is lower in preand peri-menopausal women compared to postmenopausal women while early menopause is associated with an increased risk of developing oesophageal AC [16]. Women who undergo intended curative resection of OC tend to have better overall survival compared with men [17]. These cumulative observations have led us to hypothesize that oestrogen signalling pathways play a role in the biological behaviour of OC.

In addition to the its roles in a diverse range of body tissues, oestrogens e.g. 17- $\beta$ oestradiol are implicated in the development and progression of cancers, most obviously in breast cancer [18]. Recent reports also demonstrate involvement of oestrogen signalling in the carcinogenesis of non-classical oestrogen-sensitive tissues including colon, prostate, lung, skin, and brain [1923]. The complex biological effects of oestrogens are mediated by two distinct receptor subtypes - ER $\alpha$ and ER $\beta$ (ER) and involve crosstalk between many proteins and signalling pathways [24, 25]. ER expression profiles in cancers of the breast, colon, skin, prostate and lung have been investigated extensively [26-30] and a probable role for ER in OC is suggested in a few studies on the basis of protein expression [31,32]. While functional involvement of ER in OC is not well understood, the selective oestrogen modulator (SERM) tamoxifen appears to have an antiproliferative effect and to enhance cytotoxicity of conventional chemotherapy [32-34]. Thus there is a need to further probe mechanisms by which ER contribute to OC progression. This study addresses the notion that ER play a role in the biological behaviour of OC providing evidence for their potential utility as therapeutic targets in this malignancy OC.

\section{Methods}

\section{Patient cohort}

Joint ethical approval for the research protocol (08/ H040/50) was acquired from the Derbyshire Research Ethics Committee and Derbyshire Hospitals Research and Development office. Written, informed consent was obtained from all patients included in this study. OC samples and matched normal tissue taken from adjacent macroscopic mucosa from the same patient were collected from resected $\mathrm{OC}$ specimens of 34 patients (adenocarcinoma $-n=28$; squamous cell carcinoma - $n$ =6) who underwent oesophagectomy between January 2011 and January 2013. Normal samples were microscopically examined by a consultant pathologist to confirm normal features.

\section{Cell lines}

Two human oesophageal cell lines (OE19 - a male adenocarcinoma and OE33 - a female adenocarcinoma, Sigma-Aldrich, Poole, UK) were used in this study. Cells were routinely cultured at $37{ }^{\circ} \mathrm{C}$ with $5 \% \mathrm{CO}_{2}$ in the presence of penicillin $(10,000 \mathrm{U} / \mathrm{ml})$, and streptomycin $(100 \mu \mathrm{g} / \mathrm{ml})$ using RPMI-1640 media supplemented with $10 \%$ fetal calf serum (FCS). The presence of ER $\alpha$ and ER $\beta$ receptors in OE19 and OE33 cell lines was confirmed by immunofluorescence staining using an antiER $\alpha$ antibody (Santa Cruz, CA, USA) and anti-ER $\beta$ antibody (Novacastra, Newcastle, UK).

\section{mRNA analysis by qRT-PCR}

Total RNA was extracted from tissue samples $(30 \mathrm{mg}$ ), ground in liquid $\mathrm{N}_{2}$ with a pestle and mortar and from cell lines $\left(10^{4}\right.$ cells) using the RNeasy Mini kit method (QIAGEN, UK) as per manufacturer's protocol. $300 \mathrm{ng}$ of total RNA was reverse transcribed with $(+\mathrm{RT})$ or without $(-\mathrm{RT})$ reverse transcriptase (RT) using the high-capacity cDNA reverse transcription kit (Life Technologies, Paisley, UK). $2 \mu \mathrm{l}$ of cDNA were amplified by real time PCR with commercially available TaqMan assays (Life Technologies, Paisley, UK) for ESR1 (Hs00174860_m1), ESR2 (Hs01100353_m1), and the reference genes GAPDH (Hs02758991_g1), PGK1 (Hs00943178_g1), and ACTB (Hs01060665_g1) in a Chromo 4 thermal cycler (Bio-Rad Laboratories LTD, Hemel Hempstead, UK). Expression of ESR1 and ESR2 was quantified relative to the geometric mean of three reference genes and reported as relative to max using the GenEX software Version 5 (MultiD, DE) in accordance with MIQE guidelines [35] (Additional file 1: Figure S1).

\section{Immunohistochemistry}

Immunohistochemistry (IHC) slides were prepared in the Histopathology Department at the Royal Derby Hospital. Normal mucosa and OC samples were stained using ER $\alpha$ and ER $\beta$ antibodies (NCL-L-ER-6F11 and 6007907, respectively, Novacastra, Newcastle, UK). ER $\alpha$ and ER $\beta$ positive breast cancer samples were used as positive controls. The ' $\mathrm{H}$-score method was used to measure the strength of ER-staining in normal oesophageal mucosa) and matched tumour samples [36]. Positive staining was defined as an $\mathrm{H}$-score $\geq 10$ in this study.

\section{Proliferation and cell death assays}

In preparation for cell proliferation assays, cells were cultured at a final cell number of 50,000 cells/ $\mathrm{ml}$ in phenol red-free RPMI media (Sigma-Aldrich, Poole, UK) to eliminate the weak oestrogenic effect of this indicator. This media was supplemented with $10 \%$ stripped FCS to remove any steroids in the serum. Cells were cultured in the absence or presence of $17 \beta$-estradiol (E2), an ER $\alpha$ and ER $\beta$ agonist; the highly selective ER $\alpha$ antagonist 1,3Bis(4-hydroxyphenyl)-4-methyl-5-[4-(2-piperidinylethoxy) phenol]-1H-pyrazole dihydrochloride (MPP), or ER $\beta$ 
antagonist 4-[2-Phenyl-5,7-bis (trifluoromethyl) pyrazolo[1,5-a]pyrimidin-3-yl]phenol (PHTPP) (Tocris Bioscience, Bristol, UK). The 5'-bromo-2'-deoxyuridine (BrdU) cell proliferation assay kit (Roche-Applied-Science, Burgess Hill, UK) was used to measure replication of genomic DNA as an indirect parameter of the cell proliferation rate. The Caspase-Glo 3/7 apoptosis assay (Promega, Southampton, UK) and the lactate dehydrogenase activity (LDH) assay (Sigma-Aldrich, Poole, UK) were used to determine the cell proliferation rates in the presence of the MPP or PHTPP.

\section{Statistical analysis}

For qRT-PCR on primary tissues, the two-tailed Wilcoxon signed rank test was used for matched cases while the two-tailed Mann-Whitney $U$ test was used for nonmatched variables. Either the two-tailed Mann-Whitney $U$ test or Kruskal-Wallis test, as appropriate, was used to establish relationships between hormone levels, ER mRNA and clinico-pathological features. Data for proliferation assays of the two cell lines is expressed as mean $\pm \mathrm{SD}$ of three replicates. Two-tailed Student's t-test was used for comparison of two groups. Comparison of multiple groups was performed using analysis of variance (ANOVA) followed by Dunnett's or Bonferroni's posthoc test. Statistical differences were calculated using SPSS Statistics for Windows ${ }^{\mathrm{Tm}}$ v21 software from IBM SPSS Statistics (Feltham, UK) and GraphPad Prism v6 (La Jolla, CA, USA). A value of $p \leq 0.05$ was considered as statistically significant.

\section{Results}

\section{ERa and ER $\beta$ mRNAs are increased in oesophageal tumours}

To study the expression of ER in OC, primary tissues were collected from 34 OC patients (Table 1). Median age was 65 years (range, 30-79 years). There were 28 males and 6 females with a male:female ratio (5.7:1). Twenty eight patients had oesophageal AC and six patients had oesophageal SCC. One-year disease-specific survival was $73.5 \%$. Twenty-five (74\%) patients had received neo-adjuvant therapy.

Increased expression of ESR1 (ER $\alpha)$ mRNA in oesophageal tumours relative to the matched normal tissue was observed in 21/34 patients (Fig. 1a). Overall there was a significant upregulation of ESR1 (ER $\alpha)$ mRNA in oesophageal tumour samples in comparison to matched normal mucosal samples $(p=0.035)$ (Fig. 1b). Similar findings were obtained for $\operatorname{ESR2}(\mathrm{ER} \beta)$ mRNA where increased expression was detected in tumours samples from 24 patients (Fig. 1c). The difference in expression between tumours and matched normal samples within the cohort was statistically significant $(p=0.017)$ (Fig. 1d).
Table 1 Patients' Characteristics

\begin{tabular}{|c|c|c|}
\hline Patients recruited & & 34 \\
\hline Median age (years) & & 65 (range, 30-79) \\
\hline $\begin{array}{l}\text { One-year disease-specific } \\
\text { survival }\end{array}$ & & $73.5 \%$ \\
\hline \multirow[t]{2}{*}{ Gender } & Male & $28(83 \%)$ \\
\hline & Female & $6(17 \%)$ \\
\hline \multirow[t]{2}{*}{ Histology } & Adenocarcinoma & $28(76 \%)$ \\
\hline & $\begin{array}{l}\text { Squamous } \\
\text { cell carcinoma }\end{array}$ & $6(24 \%)$ \\
\hline \multirow{3}{*}{$\begin{array}{l}\text { Tumour depth } \\
\text { (T-stage) }\end{array}$} & $\mathrm{T} 1$ & $8(24 \%)$ \\
\hline & $\mathrm{T} 2$ & $3(9 \%)$ \\
\hline & T3 & $23(67 \%)$ \\
\hline \multirow[t]{2}{*}{ Nodal involvement } & $\mathrm{No}(\mathrm{NO})$ & $15(44 \%)$ \\
\hline & Yes (N1) & $19(56 \%)$ \\
\hline \multirow{2}{*}{$\begin{array}{l}\text { Tumour } \\
\text { differentiation }\end{array}$} & Moderate & $25(74 \%)$ \\
\hline & Poor & $9(26 \%)$ \\
\hline \multirow[t]{2}{*}{ Vascular invasion } & No & $21(62 \%)$ \\
\hline & Yes & $13(38 \%)$ \\
\hline \multirow[t]{2}{*}{ Barrett's Metaplasia } & No & $13(46 \%)$ \\
\hline & Yes & $15(54 \%)$ \\
\hline \multirow{2}{*}{$\begin{array}{l}\text { Circumferential } \\
\text { resection margin }\end{array}$} & Not involved & $23(68 \%)$ \\
\hline & Involved & $11(32 \%)$ \\
\hline \multirow[t]{2}{*}{ Preoperative chemotherapy } & No & $9(26 \%)$ \\
\hline & Yes & 25 (74\%) \\
\hline
\end{tabular}

There is ER $\beta$ but no ERa expression at the protein level $\mathrm{H}$-scores for ER $\alpha$ and ER $\beta$ expression in tumour and normal mucosa samples $(N=34)$ demonstrated that only one normal mucosa sample had mild ER $\alpha$ staining ( $\mathrm{H}$ score $=10)$ and one tumour sample expressed mild ER $\alpha$ positivity $(\mathrm{H}$-score $=30)$. The rest of the samples $(n=28)$ were negative for $\mathrm{ER} \alpha$ staining in both normal mucosa and OC. On the other hand, ER $\beta$ receptor expression was detected in normal mucosa of 21 (70\%) cases while only $14(40 \%)$ tumour samples were ER $\beta$ positive but this difference was not significant $(p=0.29)$.

\section{ER mRNA expression has prognostic significance}

To evaluate the prognostic significance of ER mRNA expression in $\mathrm{OC}$, the association of ER mRNA expression with the clinico-pathological characteristics of OC patients recruited in this study (Table 1) was analysed. When ER mRNA levels were compared to the 1-year disease-specific survival (DSS) a significant inverse association was noted, whereby upregulation of both ESR1 (ER $\alpha ; p=0.046)$ (Fig. 2a) and ESR2 (ER $\beta ; p=0.023)$ (Fig. 2b) mRNA was observed in OC samples from patients with 1-year DSS less than 12 months from their indexed date of surgery in comparison to OC samples from patients who were still alive. 

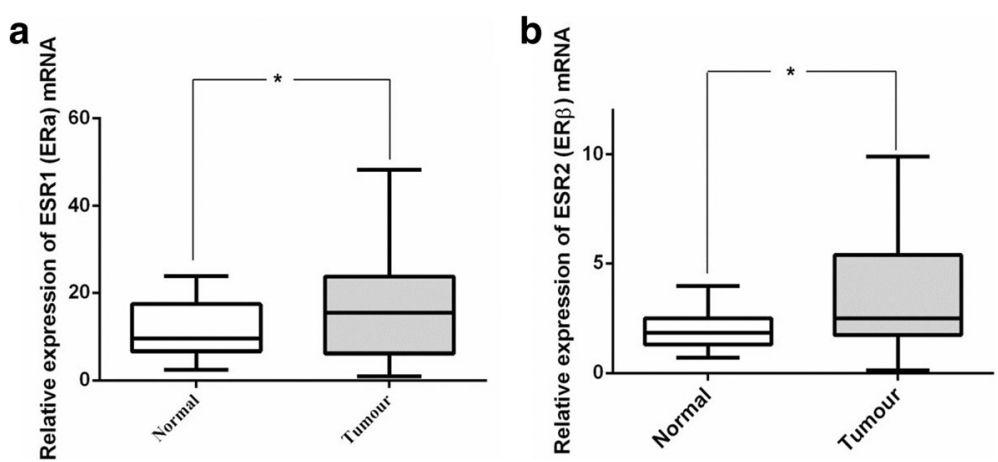

Fig. 1 ER mRNA expression increases in oesophageal cancer. a Before-and-after plot demonstrates the expression of ESR1 (ERa) mRNA in normal mucosa and oesophageal tumour samples for individual patients with oesophageal cancer $(\mathrm{N}=34)$. b Box and whisker plot demonstrates the overall expression of ESR1 (ERa) mRNA in normal mucosa and oesophageal tumour samples for 34 patients with oesophageal cancer. There is significant up-regulation of ESR1 (ERa) mRNA in oesophageal tumour samples in comparison to matched normal mucosal samples ${ }^{*} \mathrm{p}=0.035$, Wilcoxon matched pairs signed ranked test).c Before-and-after plot demonstrates the expression of ESR2 (ERß) mRNA in normal mucosa and oesophageal tumour samples for individual patients with oesophageal cancer $(N=34)$. $\mathbf{d}$ Box and whisker plot demonstrates the overall expression of ESR2 $(E R \beta)$ mRNA in normal mucosa and oesophageal tumour samples from 34 patients with oesophageal cancer. There is significant up-regulation of ESR2 (ERß) mRNA in oesophageal tumour samples in comparison to matched normal mucosal samples ( ${ }^{*} p=0.017$, Wilcoxon matched pairs signed ranked test)

The association between the expression patterns of ESR1 (ER $\alpha)$ and ESR2 (ER $\beta)$ mRNA and clinicopathological features of OC are summarised in Table 2. There was no significant gender-based difference in the expression of ESR1 $(\mathrm{ER} \alpha)$ at $\mathrm{OC}(p=0.37)$ and normal mucosal samples $(p=0.2)$. Similarly, there was no significant difference in the expression of ESR2 (ER $\beta)$ mRNA in OC samples $(p=0.37)$ nor normal mucosal samples $(p=0.31)$ among male and female patients. However, there was a significant upregulation of ESR1 (ER $\alpha)$ mRNA in OC samples from patients who had T3 tumours in comparison to $\mathrm{OC}$ samples from patients who had T1 tumours $(p=0.02)$. There was no significant difference in ESR1 (ER $\alpha)$ mRNA expression in normal mucosal samples in association with tumour depth $(p=$
0.24). Furthermore, ESR2 (ER $\beta)$ mRNA expression in T3 tumours was comparable to that of T1 tumours ( $p=$ $0.085)$. Neither was there any significant difference in the expression of ESR2 (ER $\beta)$ mRNA in normal mucosal samples from patients who had T1 and T3 tumours $(P=$ 0.53).

There was an upregulation of ESR1 (ER $\alpha)$ mRNA expression in $\mathrm{OC}$ and normal mucosa samples from patient with nodal positive disease (N1) compared to its expression in samples from patient who had no nodal involvement (N0) ( $p=0.01$ and 0.02 , respectively). In contrast, there was no significant association between the expression of ESR2 (ER $\beta)$ mRNA and nodal status either in at tumours or in normal mucosa $(p=0.15$ and 0.11 , respectively).
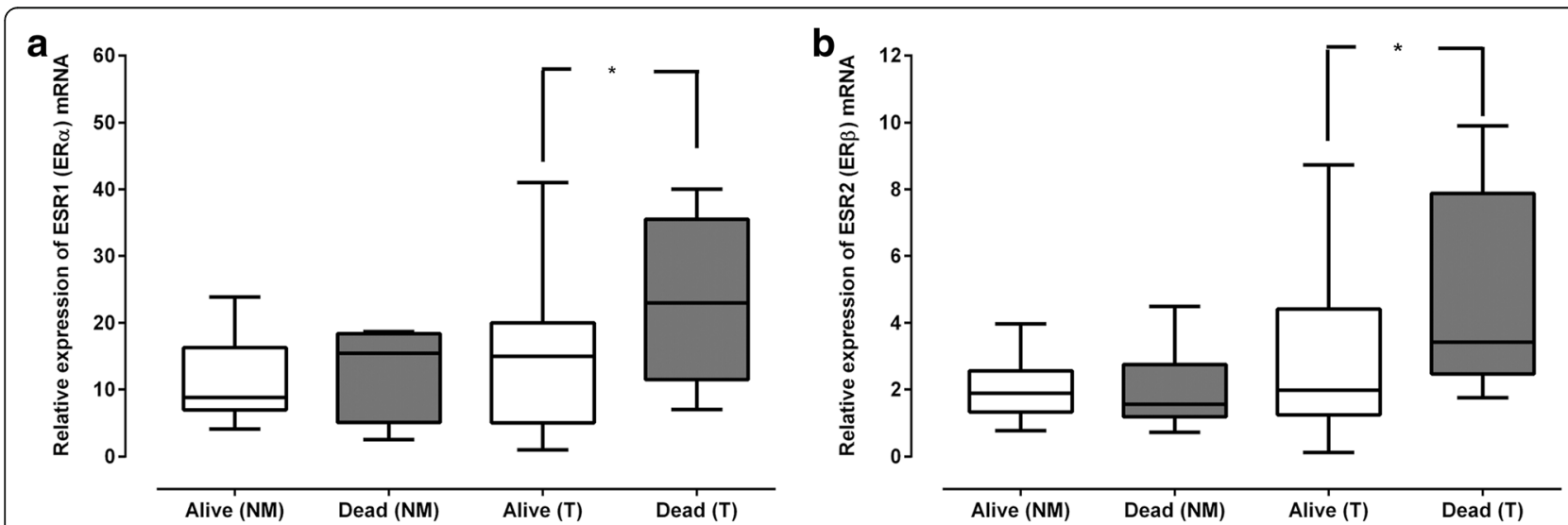

Fig. 2 There is an inverse association between ESR1 (ERa) and ESR2 (ERß) mRNA and one-year disease specific survival. a Box and whisker plot demonstrates the association of ESR1 (ERa) mRNA expression in normal mucosa and oesophageal tumour samples from patients with oesophageal cancer with one-year disease specific survival, ( ${ }^{*} p=0.046$, Mann-Whitney $U$ test). $\mathbf{b}$ Box and Whisker plot demonstrates the association of ESR2 (ER $\beta$ ) mRNA expression in normal mucosa and oesophageal tumour samples from patients with oesophageal cancer with one-year disease specific survival, ( ${ }^{*} p=0.023$, Mann-Whitney $U$ test) 
Table 2 The association between ESR1 (ERa) and ESR2 (ERB) mRNA expression and clinico-pathological characteristics

\begin{tabular}{|c|c|c|c|c|c|c|c|c|c|c|}
\hline \multirow[t]{3}{*}{ Variable } & & \multirow[t]{3}{*}{ No. } & \multicolumn{4}{|c|}{ ESR1 (ERa) mRNA expression } & \multicolumn{4}{|c|}{ ESR2 (ERß) mRNA expression } \\
\hline & & & \multicolumn{2}{|l|}{ Normal mucosa } & \multirow{2}{*}{\multicolumn{2}{|c|}{$\frac{\text { Tumour }}{\text { Median (IQR) }}$}} & \multicolumn{2}{|c|}{ Normal mucosa } & \multicolumn{2}{|l|}{ Tumour } \\
\hline & & & Median (IQR) & $p^{b}$ & & & Median (IQR) & $p^{b}$ & Median (IQR) & $p^{b}$ \\
\hline \multirow[t]{2}{*}{ Gender } & Female & 6 & $11.8(5.7,24.5)$ & 0.2 & $14.6(6.9,58.1)$ & 0.37 & $1.7(1.1,2.3)$ & 0.31 & $4.1(1.3,5.9)$ & 0.37 \\
\hline & Male & 28 & $6.9(7.2,17.8)$ & & $15.4(5.6,23.2)$ & & $1.8(1.3,3.0)$ & & $2.1(1.8,5.0)$ & \\
\hline \multirow[t]{2}{*}{ Histology } & $A C$ & 28 & $9.5(6.5,18.5)$ & 0.4 & $14.3(5.5,23.6)$ & 0.055 & $1.8(1.3,2.5)$ & 0.39 & $2.1(1.5,5.9)$ & 0.16 \\
\hline & SCC & 6 & $11.2(6.9,15.3)$ & & $22.6(18.4,25.2)$ & & $1.7(1.1,2.5)$ & & $3.1(2.1,6.0)$ & \\
\hline \multirow[t]{3}{*}{ T-stage $^{a}$} & pT1 & 8 & $8.4(7.6,14.2)$ & 0.24 & $9.5(3.3,15.8)$ & 0.02 & $1.7(1.2,3.6)$ & 0.53 & $2.0(0.9,5.4)$ & 0.085 \\
\hline & pT2 & 3 & $5.7(2.5,13.8)$ & & $5.7(5.3,8.9)$ & & $0.8(0.7,3.5)$ & & $1.7(0.5,1.8)$ & \\
\hline & pT3 & 23 & $14.7(6.3,18.7)$ & & $20(13,31)$ & & $1.9(1.35,27)$ & & $3.1(1.8,5.6)$ & \\
\hline \multirow[t]{2}{*}{ LN status $^{a}$} & NO & 15 & $7.8(6.1,13.4)$ & 0.01 & $9.7(5.4,19.7)$ & 0.02 & $1.4(1.3,2.7)$ & 0.15 & $2.0(1.0,5.3)$ & 0.11 \\
\hline & N1 & 19 & $15.9(7.8,21.3)$ & & $18.2(7.3,40.5)$ & & $1.9(1.4,2.4)$ & & $3.1(1.8,7$ & \\
\hline \multirow[t]{2}{*}{ Grade $^{a}$} & Moderate & 25 & $10.2(6.7,18.4)$ & & $15.3(6.0,22.5)$ & & $1.8(1.2,2.7)$ & & $2.8(1.8,6.1)$ & \\
\hline & Poor & 9 & $7.8(5.4,16.3)$ & & $19.7(6.0,36.6)$ & & $1.9(1.3,2.6)$ & & $1.8(1.0,5.1)$ & \\
\hline \multirow[t]{2}{*}{$\mathrm{Vl}^{\mathrm{a}}$} & No & 21 & $8.8(6.2,22.3)$ & 0.42 & $14.8(5.1,21.4)$ & 0.07 & $1.9(1.3,2.9)$ & 0.41 & $2.0(0.9,4.4)$ & 0.01 \\
\hline & Yes & 13 & $10.2(7.8,16.9)$ & & $17.0(10.7,28.1)$ & & $1.8(1.3,2.3)$ & & $3.3(2.9,7.1)$ & \\
\hline \multirow[t]{2}{*}{ BM } & Yes & 13 & $13.4(6.4,21.3$ & 0.26 & $14.6(6.1,18.7)$ & 0.31 & $2.1(1.3,5.9)$ & 0.12 & $1.7(1.2,2.9)$ & 0.054 \\
\hline & No & 15 & $6.3(2.5,16.6)$ & & $14.8(5.1,44.4)$ & & $1.9(1.3,2.3)$ & & $2.8(1.7,5.5)$ & \\
\hline \multirow[t]{2}{*}{ CRM } & No & 23 & $13.4(6.7,21.3)$ & 0.21 & $14.8(5.7,20.3)$ & 0.12 & $1.9(1.2,2.7)$ & 0.44 & $2.0(1.0,7.2)$ & 0.09 \\
\hline & Yes & 11 & $8.6(6.0,16.6)$ & & $22.5(7.3,25.7)$ & & $1.8(1.3,2.4$ & & $2.1(1.5,3.1)$ & \\
\hline
\end{tabular}

$A C$ oesophageal adenocarcinoma, SCC squamous cell carcinoma, $p T$ stage is tumour's depth, $L N$ status is lymph node involvement, $B M$, Barrett's metaplasia, $C R M$, circumferential resection margin, $I Q R$ interquartile range

${ }^{a}$ The 7th TNM Classification of Malignant Tumours proposed by the AJCC/UICC (Sobin LH, 2010)

${ }^{b}$ Analysis performed Mann Whitney U test and Kruskal-Wallis test as appropriate

There was no significant association between ESR1 $(\mathrm{ER} \alpha)$ mRNA or ESR2 (ER $\beta)$ mRNA and vascular invasion $(\mathrm{VI})$ at the normal mucosal level $(p=0.42$ and $p=$ 0.41 , respectively). In contrast, there was increased expression of ESR2 (ER $\beta)$ mRNA in OC samples from patients who had VI in comparison to cancer samples from patient who had no VI $(p=0.01)$. Likewise, there was increased expression of ESR1 (ER $\alpha)$ mRNA in tumours with VI compared to tumours with no VI but was not significant $(p=0.07)$. Furthermore, there was no significant association $(p>0.05)$ between ER mRNA expression and tumour differentiation, circumferential resection margin, or Barrett's metaplasia.

\section{ER antagonists induce inhibition of cell proliferation in oesophageal cancer cell lines}

To further investigate whether ER are potential therapeutic targets in the context of $\mathrm{EC}$, in vitro experiments were performed using the oesophageal cell lines OE33 and OE19 cell lines. Firstly the effects of the ER agonist, E2, on cell proliferation were analysed. Neither stimulatory nor inhibitory effects of E2 (1, 10 and $100 \mathrm{nM})$ on OE33 and OE19 cells were observed (Additional file 1: Figure S2). In contrast, the use of antagonists specific for ER $\alpha$ (MPP; Fig. 3a and b) or ER $\beta$ (PHTPP; Fig. 3c and d) significantly inhibited OE33 and OE19 cell proliferation in a concentration-dependent fashion. Addition of E2 to the OE19 cell lines incubated with low concentrations of MPP $(3.3 \mu \mathrm{M}$; Fig. 3b) or PHTPP $(3.3 \mu \mathrm{M}$; Fig. $3 \mathrm{~d})$ at the $48 \mathrm{~h}$ time point, demonstrated slight but significant stimulation of proliferation $(p=$ 0.01). However, E2 $(100 \mathrm{nM})$ produced no effect on the proliferation of OE33 cells incubated with MPP (Fig. 3a) or PHTPP (Fig. 3c) $(p>0.05)$.

\section{ER antagonists promote apoptosis}

To investigate the mechanism underlying the reduction in OC cell line proliferation induced by ER antagonists, further work was performed using OE33 cells to test for Caspase3/7 and lactate dehydrogenase activities. There was significant increased activity of caspase $3 / 7$ of OE33 cell lines treated with MPP $1 \mu \mathrm{M}, 3.3 \mu \mathrm{M}, 10 \mu \mathrm{M}$, and $33 \mu \mathrm{M}(p<0.0001)$ but not in cells incubated with MPP $75 \mu \mathrm{M}(p=0.5)$ compared to OE33 cells cultured with no added drugs (Fig. 4a). Similarly, the activity of caspase 3/7 of OE33 cell lines was significantly raised when cells were incubated with PHTPP $1 \mu \mathrm{M}, 33 \mu \mathrm{M}$, and $75 \mu \mathrm{M}$ compared to the negative control $(p<0.05)$ (Fig. 4b). Increased activity was also noted in cells treated with PHTPP $3.3 \mu \mathrm{M}$ and $10 \mu \mathrm{M}$, however the results did not reach statistical significance $(p=0.12$; Fig. 4b). 

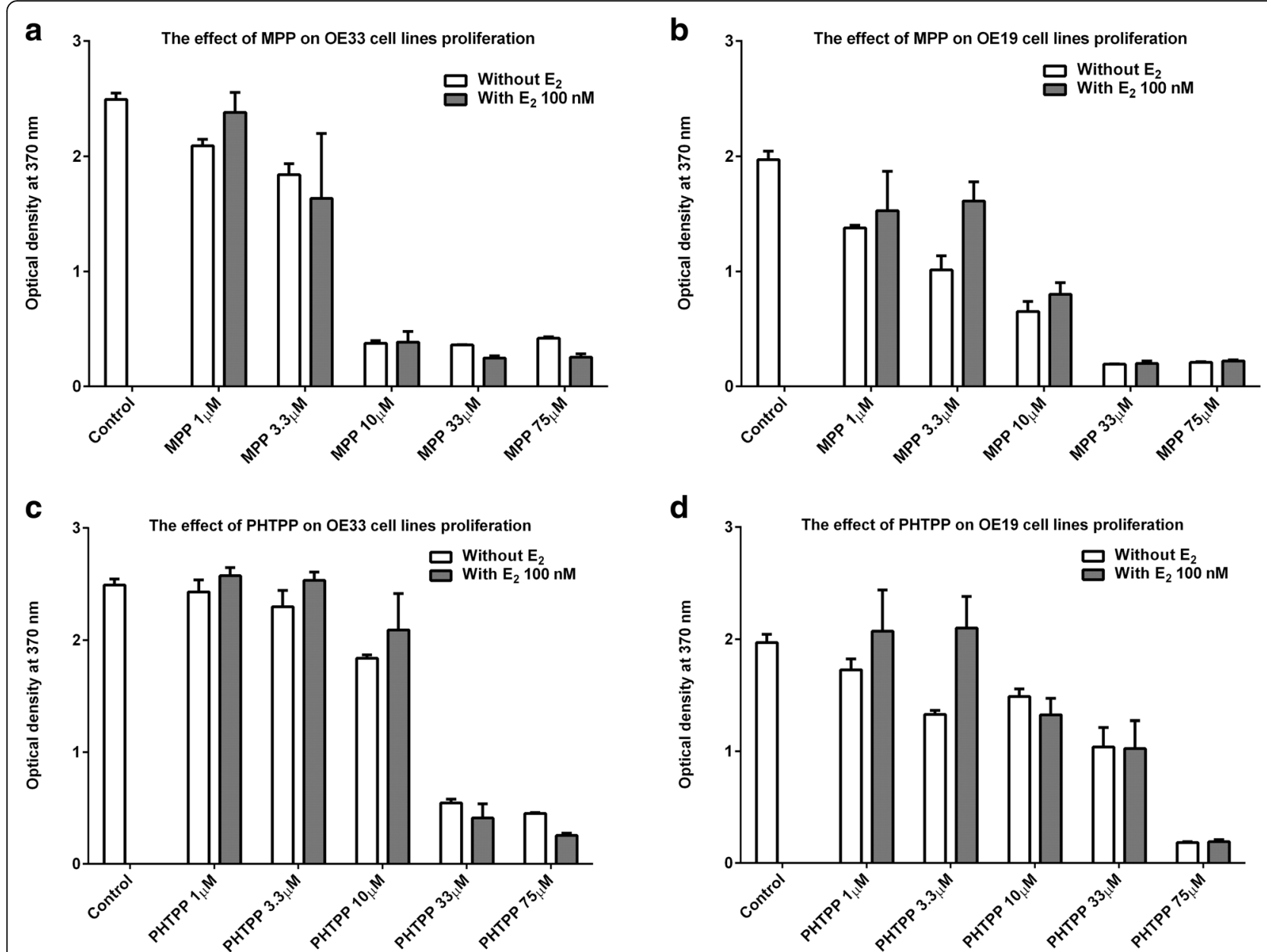

Fig. 3 MPP and PHTPP affect proliferation of OE33 and OE19 cells. Bar chart demonstrates the effect of increasing dose of MPP and PHTPP on OE33 and OE19 cell line proliferation. Cells were seeded in triplicate using a 96-well plate at a density of 5000 cells/100 $\mu$ l (without E2). At the $24 \mathrm{~h}$ time point, 5 different concentrations of MPP $(1 \mu \mathrm{M}, 3.3 \mu \mathrm{M}, 10 \mu \mathrm{M}, 33 \mu \mathrm{M}$ and $75 \mu \mathrm{M})$ or PHTPP $(1 \mu \mathrm{M}, 3.3 \mu \mathrm{M}, 10 \mu \mathrm{M}, 33 \mu \mathrm{M}$ and $75 \mu \mathrm{M})$ were added to their corresponding wells. Another set of triplicates of OE33 and OE19 cells were incubated with MPP $(1 \mu \mathrm{M}, 3.3 \mu \mathrm{M}, 10 \mu \mathrm{M}$, $33 \mu \mathrm{M}$ and $75 \mu \mathrm{M})$ or PHTPP $(1 \mu \mathrm{M}, 3.3 \mu \mathrm{M}, 10 \mu \mathrm{M}, 33 \mu \mathrm{M}$ and $75 \mu \mathrm{M})$ grown in similar conditions, with the only exception being that E2 was added (with E2) at the $48 \mathrm{~h}$ time point. The proliferation rate for OE33 and OE19 cell lines was evaluated using the BrdU proliferation assay at $72 \mathrm{~h}$ time point. a MPP (without E2) showed dose-dependent inhibition of OE33 cell line proliferation $(p<0.0001)$. Adding E2 after $24 \mathrm{~h}$ (MPP + E2) produced no changes in the proliferation rate. $\mathbf{b}$ MPP (without E2) showed dose-dependent inhibition of OE19 cell line proliferation ( $p<$ 0.0001). Adding E2 after $24 \mathrm{~h}$ (MPP + E2) lead to increase of proliferation of OE19 cell line incubated with low concentrations of MPP (1 $\mu$ M and $3.3 \mu \mathrm{M})$ only $(p<0.05)$. c PHTPP (without E2) showed dose-dependent inhibition of OE33 cell line proliferation $(p<0.0001)$. Adding E2 after $24 \mathrm{~h}$ (PHTPP + E2) produced no changes in the proliferation rate. $\mathbf{d}$ PHTPP (without E2) showed dose-dependent inhibition of OE19 cell lines proliferation ( $p<0.0001)$. Adding E2 after 24 h (PHTPP + E2) lead to increase of proliferation of OE19 cell line incubated with low concentrations of PHTPP $(1 \mu \mathrm{M}$, and $3.3 \mu \mathrm{M})$ only $(p<0.05)$

In the presence of MPP, there was an increase in the LDH activity in the supernatant taken from OE33 cell lines incubated with MPP $33 \mu \mathrm{M}$ and $75 \mu \mathrm{M}(p<0.001)$ compared to the negative control (Fig. 4c). There was no change in LDH activity in supernatants isolated from cells incubated with PHTPP at $1 \mu \mathrm{M}, 1 \mu \mathrm{M}, 3.3 \mu \mathrm{M}$, $10 \mu \mathrm{M}$, and $75 \mu \mathrm{M}(p=0.9)$ (Fig. $4 \mathrm{~d})$.

\section{Discussion}

This study describes investigations of ER expression in OC samples versus normal mucosa and potential prognostic implications. It also demonstrates the effect of highly selective ER antagonists on OC cell proliferation in vitro and the possible underlying mechanism behind reduced proliferation rates. Initially, the expression of ER was measured using qRT-PCR in normal mucosa and tumour samples from patients with potentially resectable OC. The measurement of mRNA levels demonstrated that both ER subtypes are expressed in normal mucosa and tumour samples. Additionally, there was a significant upregulation of ER $\alpha$ and ER $\beta$ mRNA expression in OC biopsies compared to their matched mucosal 

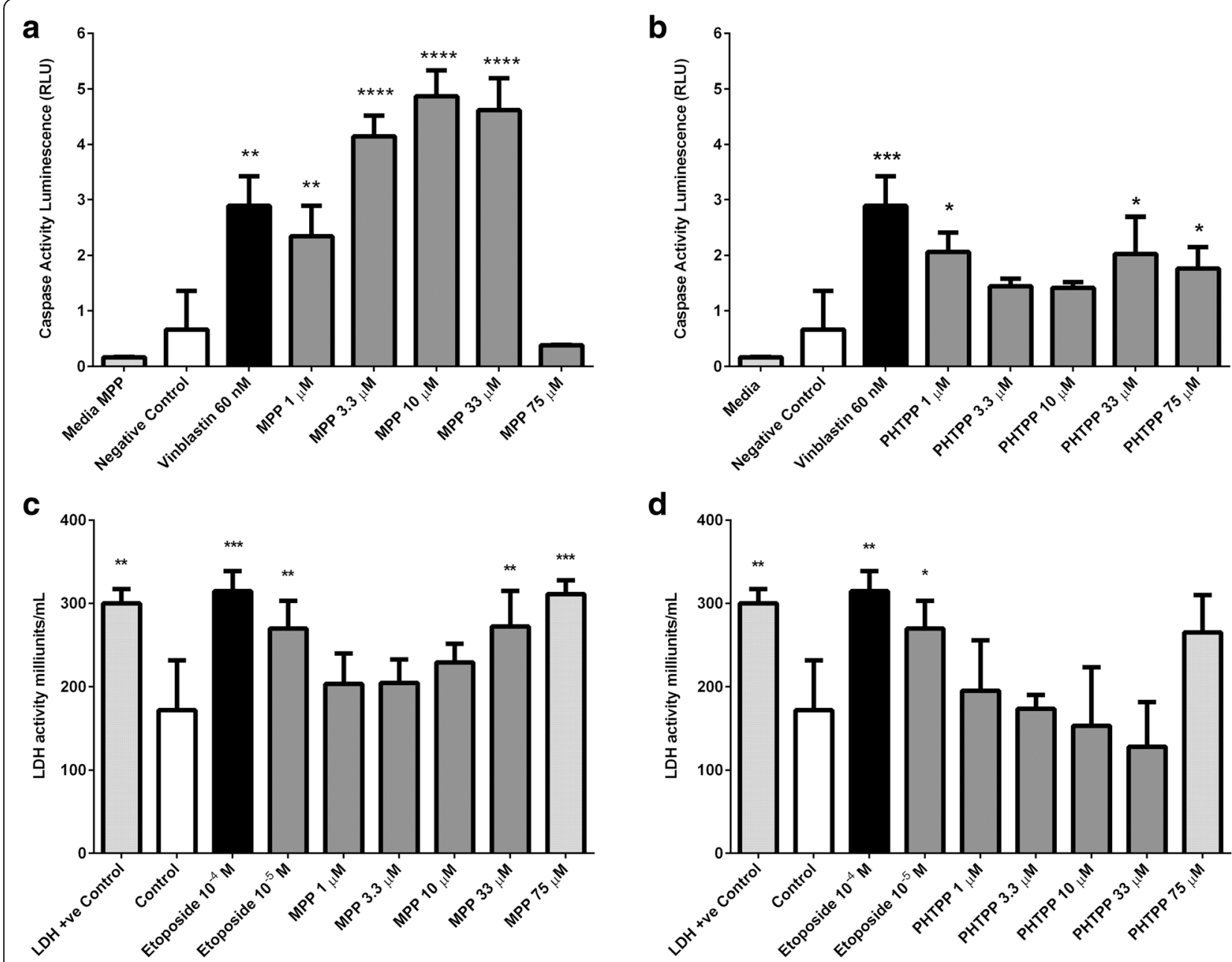

Fig. 4 Effect of MPP and PHTPP on the caspase-3/ caspase-7 activity and on the lactate dehydrogenase activity (LDH) of OE33 cell lines. Cells were treated with the indicated concentrations of MPP and PHTPP for $48 \mathrm{~h}$, and then caspase activity was determined using Caspase-Glo 3/7 assay while LDH activity was determined using LDH activity assay. Data are presented as mean \pm SD of two independent experiments. a There was a significant increase in caspase 3/7 activity of cells treated with MPP $1 \mu \mathrm{m}, 3.3 \mu \mathrm{m}, 10 \mu \mathrm{m}$, and $33 \mu \mathrm{m}$ compared to the negative control $\left({ }^{* * *} \mathrm{p}<0.0001\right)$. b There was a significant increase in caspase $3 / 7$ activity of cell treated with PHTPP $1 \mu \mathrm{m}, 33 \mu \mathrm{m}$, and $75 \mu \mathrm{m}$ compared to the negative control $\left({ }^{*} p<0.05\right)$. c There was a significant increase in the LDH activity of cells treated with MPP $33 \mu \mathrm{m}$ and $75 \mu \mathrm{m}$ compared to the negative control (*** $<0.001)$. d Only cells treated with PHTPP $75 \mu \mathrm{m}$ showed increased LDH activity compared to the negative control, however the difference did not reach statistical significance $(p=0.24)$

samples. It was also demonstrated that ER $\alpha$ and $E R \beta$ may have a potential prognostic role on the basis that mRNA levels for both receptors have a significant inverse association with one-year disease-specific survival and certain clinico-pathological features. In vitro experiments performed using oesophageal cell lines OE33 and OE19 demonstrated significant concentration-dependent inhibition of cell proliferation using selective ER antagonists in both cell lines.

ER have an essential role in the proliferation and differentiation of normal tissues and consequently oestrogen signalling may also play a role in the dysregulation of these processes in cancer cells [37]. In addition, altered expression of ER is considered as an initial step towards the development of certain cancers [24]. For instance, loss of ER $\beta$ increases proliferation of colon cancer cell lines [38] while increased ER $\beta$ expression leads to cell cycle arrest $[39,40]$. In the breast, ER $\alpha$ mediates the proliferative effect of E2 and ER $\beta$ has antiproliferative effects $[41,42]$. In prostate cancer, the expression of ER $\beta$ undergoes gradual reduction in the expression from normal tissue to benign prostatic hyperplasia towards invasive prostate cancer [43]. Furthermore, the re-introduction of ER $\beta$ into prostatic cancer cell lines was associated with decreased proliferation and increased apoptosis [22]. A recent study from Germany investigated the significance of ER $\alpha$ expression in nonsmall cell lung cancer (NSCLC) samples from 64 
patients who underwent radiotherapy treatment [44]. It was found that ER $\alpha$ expression in NSCLC inversely associated with disease-free and overall survival [44]. The number of studies investigating ER status in OC is scarce and the results are rather conflicting and inconclusive. Nevertheless, it was suggested that ER $\beta$ is the predominant receptor in oesophageal normal mucosa and OC while ER $\alpha$ is only expressed at very low levels [31, 45-49]. The presence of ER subtypes at the mRNA level in normal mucosa has prompted us to postulate that ER play a role in normal oesophageal function. Moreover, the observation of increased expression of ER subtypes in tumour samples may also indicate a biological role in OC development.

It has been suggested that oestrogens confer protective effects on the development of OC. In this study, the effect of E2 on OC proliferation in vitro demonstrated no significant changes in proliferation rates of the OE33 and OE19 cell lines when cells were incubated with increasing concentrations of E2. However, there was significant inhibition of OE33 and OE19 cell lines by increasing the concentrations of a highly selective ER $\alpha$ antagonist (MMP) and an ER $\beta$ antagonist (PHTPP). In addition, it was also demonstrated that the mechanism behind this reduction in cell growth rate is the initiation of a programmed cell death rather than a direct cytotoxic effect. These findings support our hypothesis that oestrogen signalling pathways may have a role in the biological behaviour of OC. However, further studies of cell-cycle analysis are necessary to distinguish the molecular mechanisms behind these findings $[50,51]$.

The effect of E2 via ER is influenced by several factors. Hence, the finding of no altered proliferation rate in response to E2 may be due to the fact that OC cell lines express ER $\alpha$ and ER $\beta$ at similar levels and activation of one receptor could have antagonised the function of the other receptor $[18,24]$ especially if the ER subtypes have opposing actions. On binding of E2 with ER, the end result is also affected by the type of co-regulators recruited into action. For instance, if a co-suppresser like Repressor of oestrogen receptor Activity (REA) is bound to the E2/ER complex, it will lead to inhibition of activation of ERE and gene transcription [24, 51, 52]. Lastly, the absence of an E2 effect can also be explained by posttranslational modifications where the E2/ER complex is promptly metabolised by ubiquitination or phosphorylation $[24,53]$.

In this study, the reason for the lack of the expression of ER $\alpha$ protein is unclear and may be theoretically explained by stating that ER $\alpha$ (ESR1) gene is simply a nonfunctional gene. However, this explanation seems rather naïve given that all normal mucosal and tumour samples used in this study demonstrated variable levels of ER $\alpha$ mRNA. Moreover, there was altered expression of ER $\alpha$
mRNA between normal mucosa and tumour samples. In addition, both OC cell lines (OE33 and OE19) demonstrated moderate expression of ER $\alpha$ at the protein level. Hence, other factors might have contributed to the ER $\alpha$ negative status in tissue samples. For example, previous studies have suggested that monoclonal antibodies can be species and tissue-specific $[54,55]$. In this study, we used mouse monoclonal antibodies for the quantification of ER $\alpha$ status. These antibodies were developed using a prokaryotic recombinant protein as an immunogen which corresponds to the full-length human ER $\alpha$ molecule. Interestingly, there was strong ER $\alpha$ staining in breast cancer tissue used as a positive control. Using the same antibodies, Kalayarasan et al. found no ER $\alpha$ expression in $45 \mathrm{OC}$ specimens $(\mathrm{SSC}=30, \mathrm{AC}=15)$ [49]. Moreover, Kawai et al. found that using monoclonal antibodies (against NH2 terminus of $\mathrm{ER} \alpha$ ) for quantification of ER $\alpha$ in NSCLC produced negative results whereas the use of polyclonal antibodies (against $\mathrm{COOH}$ terminus of ER $\alpha$ ) gave positive ER $\alpha$ staining [28]. This may suggest that ER $\alpha$ isoforms localised in oesophageal tissue may lack an epitope which is specific to monoclonal antibodies [55]. This could have contributed to the lack of ER $\alpha$ staining in our cohort [28].

To the best of our knowledge, this study is the first to investigate the ER status in patients with OC, mainly oesophageal AC from a UK population. It also builds on other studies by Sukocheva et al. [32] and Due et al. [34] where in vitro effects using a selective ER modulator on OC cell lines confirmed anti-proliferative effects observed with Tamoxifen. However, we opted to use only MPP and PHTPP rather than Tamoxifen for an important experimental reason. The agonist/antagonist property of Tamoxifen varies among tissues [56]. For instance, Tamoxifen acts as an ER antagonist on breast tissue and inhibits breast cells proliferation, however it acts as an ER agonist (i.e., mimicking the effects of oestrogen) in bone and uterine cells [56]. Its action on oesophageal cancer cells used in Sukocheva et al. [32] and Due et al. [34] is not clearly explained whether based on its antagonist or agonist property. In comparison, MPP and PTHPP are highly selective ER antagonists and blocking them allows one to suggest that any experimental effects are likely due to the involvement of these receptors.

There are a few limitations in this study. Firstly, in vitro experiments carried out to investigate the potential role of E2 and ER do not often mimic effects in vivo. For this reason, the findings may not necessarily produce similar biological effects if experiments are run in vivo. Secondly, the cancer cell lines used in this study might have undergone epigenetic modifications and so this could somewhat affect the results generated [57]. Thirdly, the work conducted in this study to address the 
change of ER status was performed on samples obtained from patients with only potentially resectable OC. Hence, it is not known whether comparable results are still possibly obtainable if samples are collected from patients with locally advanced or metastatic disease. Finally, neither the effect of E2 or ER modulators on normal oesophageal epithelial physiology nor ER status in normal oesophageal mucosa samples obtained from patients with non-malignant oesophageal pathologies were investigated.

\section{Conclusion}

Our findings indicate a possible role for ER in the biological behaviour of OC. We demonstrate that a significant increase of ER mRNA levels in OC which inversely correlates with survival and pathological features. Furthermore, selective blocking of ER inhibited OC cell proliferation. Further studies examining ER as novel targets for the treatment of $\mathrm{OC}$ are required.

\section{Additional file}

Additional file 1: Figure S1. Identification of suitable reference genes. Reference genes expression stability was analysed using geNorm and NormFinder. Figure S2. E2 treatment does not alter proliferation of OE33 and OE19 cells. Bar chart demonstrates the effect of increasing dose of E2 on OE33 and OE19 cell lines proliferation. (PDF 348 kb)

\section{Abbreviations}

+RT: Positive reverse transcribed; AC: Adenocarcinoma; E2: 17/-estradiol; ER: Oestrogen receptors; ERa: Oestrogen receptor alpha; ERB: Oestrogen receptor beta; ESR1: ERa gene; ESR2: ER $\beta$ gene; FCS: Fetal calf serum; MPP: Highly selective ERa antagonist 1,3-Bis(4-hydroxyphenyl)-4-methyl-5-[4-(2piperidinylethoxy)phenol]-1H-pyrazole dihydrochloride; OC: Oesophageal cancer; OE19: Male oesophageal adenocarcinoma cell line; OE33: Female oesophageal adenocarcinoma cell line; PTHPP: ER $\beta$ antagonist 4-[2-Phenyl5,7-bis (trifluoromethyl) pyrazolo[1,5-a]pyrimidin-3-yl]phenol; -RT: Negative reverse transcriptase; RT-PCR: Reverse transcription polymerase chain reaction

\section{Acknowledgements}

The authors thank Professor I O Ellis, Dr David Semeraro, Mrs Averyl Warren and Mrs Andrea Gooding for providing technical support in the laboratory.

\section{Funding}

No external funding.

\section{Availability of data and materials}

This research project is still currently in progress and authors would prefer to refrain from publishing any data at present.

\section{Authors' contributions}

WA, CT, RK, and SYI have had substantial contributions to conception and design; drafting the article or revising it critically for important intellectual content. All authors read and approved the final manuscript.

\section{Ethics approval and consent to participate}

Joint ethical approval for the research protocol (08/H040/50) was acquired from regional Derbyshire Research Ethics Committee and Derbyshire Hospitals Research and Development office. Written, informed consent was obtained from all patients included in this study.

\section{Consent for publication}

Not applicable.

\section{Competing interests}

All authors declare that they have no competing interests.

\section{Publisher's Note}

Springer Nature remains neutral with regard to jurisdictional claims in published maps and institutional affiliations.

Received: 16 May 2016 Accepted: 23 January 2018

Published online: 01 February 2018

\section{References}

1. Jemal A, et al. Global cancer statistics. CA Cancer J Clin. 2011;61(2):69-90.

2. Kim T, et al. Esophageal cancer-the five year survivors. J Surg Oncol. 2011; 103(2):179-83.

3. Umar SB, Fleischer DE. Esophageal cancer: epidemiology, pathogenesis and prevention. Nat Clin Pract Gastroenterol Hepatol. 2008;5(9):517-26.

4. Naughton P, Walsh TN. Multimodality therapy for cancers of the esophagus and gastric cardia. Expert Rev Anticancer Ther. 2004;4(1):141-50.

5. Lagergren J, Lagergren P. Recent developments in esophageal adenocarcinoma. CA Cancer J Clin. 2013;63(4):232-48.

6. Mathieu $L N$, et al. Age and sex differences in the incidence of esophageal adenocarcinoma: results from the surveillance, epidemiology, and end results (SEER) registry (1973-2008). Dis Esophagus. 2013; p. n/a-n/a

7. Lagergren J. Adenocarcinoma of oesophaqus: what exactly is the size of the problem and who is at risk? Gut. 2005;54(Suppl 1):i1-5.

8. Brown LM, Devesa SS, Chow WH. Incidence of adenocarcinoma of the esophagus among white Americans by sex, stage, and age. J Natl Cancer Inst. 2008;100(16):1184-7.

9. Edgren $\mathrm{G}$, et al. Enigmatic sex disparities in cancer incidence. Eur J Epidemiol. 2012;27(3):187-96.

10. Lofdahl HE, Lu Y, Lagergren J. Sex-specific risk factor profile in oesophageal adenocarcinoma. Br J Cancer. 2008;99(9):1506-10.

11. Lindblad $\mathrm{M}$, et al. Hormone replacement therapy and risks of oesophageal and gastric adenocarcinomas. Br J Cancer. 2006;94(1):136-41.

12. Rutegard $\mathrm{M}$, et al. Oesophageal adenocarcinoma: the new epidemic in men? Maturitas. 2011;69(3):244-8.

13. Derakhshan $\mathrm{MH}$, et al. Oesophageal and gastric intestinal-type adenocarcinomas show the same male predominance due to a 17 year delayed development in females. Gut. 2009;58(1):16-23.

14. Freedman ND, et al. The association of menstrual and reproductive factors with upper gastrointestinal tract cancers in the NIH-AARP cohort. Cancer. 2010;116(6):1572-81

15. Bodelon C, et al. Hormonal factors and risks of esophageal squamous cell carcinoma and adenocarcinoma in postmenopausal women. Cancer Prev Res (Phila). 2011;4(6):840-50.

16. Green J, et al. Reproductive factors and risk of oesophageal and gastric cancer in the million women study cohort. Br J Cancer. 2012;106(1):210-6.

17. Morita $\mathrm{M}$, et al. Gender differences in prognosis after esophagectomy for esophageal cancer. Surg Today. 2013:1-8.

18. Nilsson S, Gustafsson JA. Estrogen receptors: therapies targeted to receptor subtypes. Clin Pharmacol Ther. 2011;89(1):44-55.

19. Williams $C$, et al. Estrogen receptor beta as target for colorectal cancer prevention. Cancer Lett. 2016;372(1):48-56.

20. Li W, Tse LA, Wang F. Prognostic value of estrogen receptors mRNA expression in non-small cell lung cancer: a systematic review and metaanalysis. Steroids. 2015;104:129-36.

21. Luo Z, et al. Overexpression of estrogen receptor beta is a prognostic marker in non-small cell lung cancer: a meta-analysis. Int J Clin Exp Med. 2015:8(6):8686-97.

22. Walton TJ, et al. DNA demethylation and histone deacetylation inhibition co-operate to re-express estrogen receptor beta and induce apoptosis in prostate cancer cell-lines. Prostate. 2008;68(2):210-22.

23. Jia M, Dahlman-Wright K, Gustafsson J-Å. Estrogen receptor alpha and beta in health and disease. Best Prac Res Clin Endocrinol Metabol. 2015;29(4): 557-68

24. Thomas C, Gustafsson JA. The different roles of ER subtypes in cancer biology and therapy. Nat Rev Cancer. 2011;11(8):597-608.

25. Nilsson S, et al. Mechanisms of estrogen action. Physiol Rev. 2001;81(4): $1535-65$.

26. Chen GG, Zeng Q, Tse GMK. Estrogen and its receptors in cancer. Med Res Rev. 2008;28(6):954-74. 
27. Kawashima H, Nakatani T. Involvement of estrogen receptors in prostatic diseases. Int J Urol. 2012;19(6):512-22. author reply 522-3

28. Kawai $\mathrm{H}$, et al. Estrogen receptor alpha and beta are prognostic factors in non-small cell lung cancer. Clin Cancer Res. 2005;11(14):5084-9.

29. Konstantinopoulos PA, et al. Oestrogen receptor beta (ERbeta) is abundantly expressed in normal colonic mucosa, but declines in colon adenocarcinoma paralleling the tumour's dedifferentiation. Eur J Cancer. 2003;39(9):1251-8.

30. Jassam $\mathrm{N}$, et al. Loss of expression of oestrogen receptor beta in colon cancer and its association with Dukes' staging. Oncol Rep. 2005;14(1):17-21.

31. Zuguchi $M$, et al. Estrogen receptor alpha and beta in esophageal squamous cell carcinoma. Cancer Sci. 2012;103(7):1348-55.

32. Sukocheva OA, et al. Effect of estrogen on growth and apoptosis in esophageal adenocarcinoma cells. Dis Esophagus. 2013;26(6):628-35.

33. Wang BJ, et al. Hormonal and reproductive factors and risk of esophageal cancer in women: a meta-analysis. Dis Esophagus. 2015; p. n/a-n/a

34. Due SL, et al. Tamoxifen enhances the cytotoxicity of conventional chemotherapy in esophageal adenocarcinoma cells. Surg Oncol. 2016;25(3): 269-77.

35. Bustin SA, et al. The MIQE guidelines: minimum information for publication of quantitative real-time PCR experiments. Clin Chem. 2009;55(4):611-22.

36. McClelland RA, et al. Automated quantitation of immunocytochemically localized estrogen receptors in human breast cancer. Cancer Res. 1990; 50(12):3545-50.

37. Shanle EK, Xu W. Selectively targeting estrogen receptors for cancer treatment. Adv Drug Deliv Rev. 2010;62(13):1265-76.

38. Giroux $V$, et al. Estrogen receptor $\beta$ deficiency enhances small intestinal tumorigenesis in ApcMin/+ mice. Int J Cancer. 2008;123(2):303-11.

39. Martineti $V$, et al. ERß is a potent inhibitor of cell proliferation in the HCT8 human colon cancer cell line through regulation of cell cycle components. Endocr Relat Cancer. 2005;12(2):455-69.

40. Wilkins $\mathrm{H}$, et al. Estrogen prevents sustained COLO-205 human colon cancer cell growth by inducing apoptosis, decreasing c-myb protein, and decreasing transcription of the anti-apoptotic protein bcl-2. Tumor Biol. 2010;31(1):16-22.

41. Ström A, et al. Estrogen receptor $\beta$ inhibits 17 $\beta$-estradiol-stimulated proliferation of the breast cancer cell line T47D. Proc Natl Acad Sci U S A. 2004;101(6):1566-71.

42. Lin C-Y, et al. Inhibitory effects of estrogen receptor beta on specific hormone-responsive gene expression and association with disease outcome in primary breast cancer. Breast Cancer Res. 2007:9(2):R25.

43. Hartman J, Ström A, Gustafsson J-Å. Current concepts and significance of estrogen receptor $\beta$ in prostate cancer. Steroids. 2012;77(12):1262-6.

44. Rades $D$, et al. The prognostic impact of tumor cell expression of estrogen receptor-alpha, progesterone receptor, and androgen receptor in patients irradiated for nonsmall cell lung cancer. Cancer. 2012;118(1):157-63.

45. Tiffin N, et al. Sex hormone receptor immunohistochemistry staining in Barrett's oesophagus and adenocarcinoma. Histopathology. 2003:42(1):95-6.

46. Nozoe T, et al. Significance of immunohistochemical expression of estrogen receptors alpha and beta in squamous cell carcinoma of the esophagus. Clin Cancer Res. 2007;13(14):4046-50.

47. Akgun $\mathrm{H}$, Lechago J, Younes $\mathrm{M}$. Estrogen receptor-beta is expressed in Barrett's metaplasia and associated adenocarcinoma of the esophagus. Anticancer Res. 2002;22(3):1459-61.

48. Liu L, Chirala M, Younes M. Expression of estrogen receptor-beta isoforms in Barrett's metaplasia, dysplasia and esophageal adenocarcinoma. Anticancer Res. 2004;24(5A):2919-24.

49. Kalayarasan $\mathrm{R}$, et al. Estrogen and progesterone receptors in esophageal carcinoma. Dis Esophagus. 2008;21(4):298-303.

50. Driggers $\mathrm{PH}$, Segars $\mathrm{JH}$. Estrogen action and cytoplasmic signaling pathways. Part II: the role of growth factors and phosphorylation in estrogen signaling. Trends Endocrinol Metab. 2002;13(10):422-7.

51. Katzenellenbogen BS, et al. Molecular mechanisms of estrogen action: selective ligands and receptor pharmacology. J Steroid Biochem Mol Biol. 2000;74(5):279-85.

52. Cheskis BJ, et al. Signaling by estrogens. J Cell Physiol. 2007;213(3):610-7.

53. Ascenzi P, Bocedi A, Marino M. Structure-function relationship of estrogen receptor alpha and beta: impact on human health. Mol Asp Med. 2006; 27(4):299-402.

54. Tyulmenkov W, Klinge CM. Selectivity of antibodies to estrogen receptors alpha and beta (ERalpha and ERbeta) for detecting DNA-bound ERalpha and ERbeta in vitro. Steroids. 2000;65(9):505-12.
55. Pavao M, Traish AM. Estrogen receptor antibodies: specificity and utility in detection, localization and analyses of estrogen receptor alpha and beta. Steroids. 2001;66(1):1-16.

56. Robertson JF. Selective oestrogen receptor modulators/new antioestrogens: a clinical perspective. Cancer Treat Rev. 2004;30(8):695-706.

57. Ung $M$, et al. Effect of estrogen receptor a binding on functional DNA methylation in breast cancer. Epigenetics. 2014;9(4):523-32.

\section{Submit your next manuscript to BioMed Central and we will help you at every step:}

- We accept pre-submission inquiries

- Our selector tool helps you to find the most relevant journal

- We provide round the clock customer support

- Convenient online submission

- Thorough peer review

- Inclusion in PubMed and all major indexing services

- Maximum visibility for your research

Submit your manuscript at www.biomedcentral.com/submit
) Biomed Central 